\title{
Star Fruit Orchard Waste as Source of Organic Materials On Sustainable Agricultural System
}

\author{
Inanpi Hidayati Sumiasih ${ }^{*}$, Mutiara Dewi Puspitawati' ${ }^{1}$, and Ahmad Rifqi Fauzi ${ }^{1}$ \\ ${ }^{1}$ Department of Agrotechnology, Faculty of Bioindustri, Trilogi University, Indonesia \\ *Corresponding author: inanpihs@trilogi.ac.id
}

\section{ARTICLE HISTORY \\ Received : 12 February 2020 \\ Revised : 18 March 2020 \\ Accepted : 7 April 2020}

\section{KEYWORDS}

Fertilizer;

Organic waste;

Star Fruit;

Sustainable Agriculture;

\begin{abstract}
Star fruit harvesting activity in Attaqie Farm orchard produces no less than $20 \%$ of organic waste in each period. The organic waste can be utilized as an organic fertilizer source. The potential of star fruit waste as a source for liquid organic fertilizer (LOF) is an interesting subject to study. The objective of this study was to obtain information about the potential of star fruit waste as LOF and how it affects green mustard production. The study used the factorial design with two factors, namely inorganic fertilizer dosage $(0 \%, 50 \%$, and $100 \%$ of recommended dosage) and LOF concentration (0, 3, 6, and $9 \mathrm{ml} / \mathrm{L}$ ) and arranged using Completely Randomized Block Design. There were twelve combinations of treatments with three replications. The production of liquid organic fertilizer (LOF) with star fruit waste as the main ingredient used an anaerobic fermentation method with help from EM4 bio-activator for 30 days. Green mustard shoot weight increased with higher LOF concentration. The application of $9 \mathrm{ml} / \mathrm{L}$ LOF produced $20 \%$ higher green mustard shoot weight compared to without application and the application of $3 \mathrm{ml} / \mathrm{L} \mathrm{LOF}$. The result showed that LOF from star fruit waste has the potential to be developed through formulation development.
\end{abstract}

This is an open access article under the CC-BY-SA license.

\section{INTRODUCTION}

Attaqie Farm star fruit orchard in Tuban, East Java is one of developing agropolitans. The main product of this farm is Tasik Madu star fruit that can produce $100 \mathrm{~kg}$ of star fruit in each harvest time. Almost $20 \%$ of them are leftover fruits, including overripe fruits, half-eaten fruits by pests (eaten by bats and owls), partly dried fruits, and underripe fruits from thinning. The leftover fruit is left to rot and cause gas pollution in the form of odor as well as reduce the aesthetic of the farm.

Efforts to reduce the problem are still underway, including by making the star fruit waste as liquid organic fertilizer (LOF) that can be utilized as a nutrient source for the main crop (star fruit) and vegetable crop. Many researcher that reported their research about application of LOF on horticulture commodities (Sopha \& Uhan, 2013; Hardiansyah, et al, 2019; Phibunwatthanawong \& Riddech, 2019)

The utilization of farm waste become focus in solving the waste problem. Farm waste is divided into three categories, pre-harvest waste, at-harvest waste, and post-harvest waste. In this study, the star fruit waste used was pre-harvest, on harvest, up to post-harvest waste. The management of waste become focus on sustainable agriculture, especially to utilize farm waste and put it back in the soil to return nutrients from plant to soil.

The trend in using liquid organic fertilizer as an alternative to chemical fertilizer is increasing. Liquid organic fertilizer is a substance to nourish plants, made from organic materials in liquid form. The function of liquid organic fertilizer is to: fertilize plants, maintain nutrient balance in the soil, and reducing the organic waste from the environment. A good ingredient for liquid organic fertilizer is organic waste with high water content such as leftover fruits and vegetables. They are easily decomposed as well as rich in nutrients needed by crops.

Star fruit waste from thinning and leftover from harvest can be utilized as a raw material in production LOF that can be used as fertilizer for the cultivation of the vegetable crops. Result from Yulnafatmawita, et al. (2012) showed that organic compounds in liquid organic fertilizer can improve the physical and biological properties of soil, so it can increase the effectivity of nutrient absorption by plants. 
Waste is leftover material that is not used, not liked, or something that must be discarded, which generally comes from the activities carried out by humans (Fadhilah, 2011). The existence of abundant fruit waste has great potential as a source of raw material for making liquid organic fertilizer. These piles of fruit waste are rarely used by the community because they are no longer suitable for animal feed. Usually, fruit waste is left alone, causing an unpleasant odor, reduce environmental hygiene, and can be detrimental to health. As a solution to the impact caused by this fruit waste, fruit skin waste can be used as a potential alternative source of raw materials to produce liquid organic fertilizer. Organic fertilizers produced are fertilizers that are very rich in substances needed by plants. Certain compounds such as protein, cellulose, lignin, cannot be replaced by chemical fertilizers (Bayuseno, 2009).

Waste can be categorized into several types, including a. Organic waste (degradable) (a type of waste that is mostly composed of organic compounds plant residues, animals, or feces). Organic waste is easily broken down by living bodies, especially microorganisms. Inorganic waste (non-degradable); b. Inorganic waste is a type of waste that is composed of inorganic compounds (plastic, bottles, metals). Inorganic waste is very difficult to be decomposed by microorganisms (Novizan, 2005).

This study aimed to utilize star fruit waste to produce LOF and reduce the use of inorganic fertilizer in the cultivation of vegetables using verticulture system also to find out the optimal dosage of star fruit waste LOF for increasing leafy vegetable crop production.

\section{MATERIALS AND METHODS}

\subsection{Time and Place}

This study was conducted in April 2019 to November 2019. The place of the study was Attaqie Farm, Panyuran Village, Palang District, Tuban Regency, East Java. The analysis of soil and liquid organic fertilizer content was conducted in Soil Research Center, Bogor.

\subsection{Materials}

The Materials this study used green mustard seed, inorganic N fertilizer, EM-4, water, molasses, sugar, rice water. This study conducted in multilevel verticulture rack and used machetes, buckets, pans, nursery trays. To observe some variables used digital scale, digital calipers, measuring cups, stationery, and tarpaulin.

\subsection{Methods}

The experimental design used is Completely Randomized Block Design factorial. The first factor was inorganic $\mathrm{N}$ fertilizer dosage, with levels of $0 \%, 50 \%$, and $100 \%$ of the recommended dosage which is $100 \mathrm{~kg} / \mathrm{ha}$ urea. The second factor is liquid organic fertilizer dosage with four levels namely $0,3,6$, and $9 \mathrm{ml} /$ liter. Inorganic fertilizer and LOF is applied after planting. Each combination of treatments is replicated three times and within each replication, there are five individual plants, hence there are 180 experimental samples.

The method of this study consisted of three steps: (1) the production of liquid organic fertilizer (LOF) from star fruit waste; (2) Germination test of vegetable crop; (3) Efficacy test of star fruit LOF and inorganic fertilizer application in leafy vegetable cultivation.Liquid organic fertilizer (LOF) was produced using star fruit waste from Agroedutourism Attaqie Farm as raw materials. The process of making LOF is anaerobic fermentation using EM4 as the bio-activator and took 30 days. There are six formulations made, namely: 2B15E (2 kg star fruit waste \& $15 \mathrm{ml}$ EM4), 2B20E (2 kg star fruit waste \& $20 \mathrm{ml} \mathrm{EM4),}$ 4B15E (4 kg star fruit waste \& $15 \mathrm{ml} \mathrm{EM4),} \mathrm{4B20E} \mathrm{(4} \mathrm{kg}$ star fruit waste \& $20 \mathrm{ml} \mathrm{EM4),6B15E} \mathrm{(6} \mathrm{kg} \mathrm{star} \mathrm{fruit}$ waste \& $15 \mathrm{ml} \mathrm{EM4),} \mathrm{and} \mathrm{6B20E} \mathrm{(6} \mathrm{kg} \mathrm{star} \mathrm{fruit} \mathrm{waste} \mathrm{\&}$ $20 \mathrm{ml}$ EM4).

\subsection{Implementation}

The study consists of two parts. The first part is the production of liquid organic fertilizer from star fruit waste. The production of LOF is an anaerobic process using leftover star fruits from thinning, half-eaten by pests, underripe and overripe fruits. The fruit waste is fermented for 30 days. The resulted mature LOF was tested at Soil Research Center, Bogor.

The second part of the study is the application of star fruit waste LOF for green mustard cultivation in a multilevel verticulture planting system. The fertilizers are applied 5 days after planting. The application of inorganic fertilizer is by side-dressing, while the application of LOF is by pouring it straight to the plants. Observations are conducted every week by measuring plant growth and fresh shoot weight at harvest.

\subsection{Statistical Analysis}

Oberserved data was analyzed using analysis of variance (ANOVA) and further mean comparison tested using Least Significant Different tests (LSD test) when found to be significantly different in $\alpha \leq 10 \%$.

\section{RESULTS AND DISCUSSIONS}

\subsection{Formulation of liquid organic fertilizer from star fruit}

In the process of making LOF, sugar solution as molasses also mixed in. Sugar functions as a food source for microorganisms that can increase the nutrient content in the resulted fertilizer. Qualitative data collected from this part of the study were the color, odor, and froth of the LOF. The qualitative observation result is shown in Table 1. 
Table 1. Star Fruit Waste Liquid Organic Fertilizer Properties

\begin{tabular}{llll}
\hline Treatment & Color & Odor & Froth \\
\hline 2B15E & Brownish-yellow & Pungent & Present \\
2B20E & Brownish-yellow & Pungent & Present \\
4B15E & Brownish-yellow & Pungent & Present \\
4B20E & Brownish-yellow & Pungent & Present \\
6B15E & Brownish-yellow & Pungent & Absent \\
6B20E & Yellow & Pungent & Present \\
\hline
\end{tabular}

The color changes to brownish-yellow and the pungent odor that occurs in all formulations when making the star fruit waste LOF are the signs that fermentation process has happened and the organic matters have decomposed by microorganisms (Afifi, 2007). The pungent fermented smell is an indication that the LOF is matured as well as the brownish-yellow color (Hadisuwito, 2007). Furthermore, there was a white layer on the LOF surface in all formulations. The white layer was actinomycetes, a type of fungi that grows after fertilizer was made. Based on qualitative observations, there was no significant difference in all LOF formulation but the 4B20E (4 $\mathrm{kg}$ of star fruit waste \& $20 \mathrm{ml} \mathrm{EM4)}$ is the best formulation because it has stronger brownish-yellow compared to other formulations. The picture of LOF formulations is shown in Figure 1.

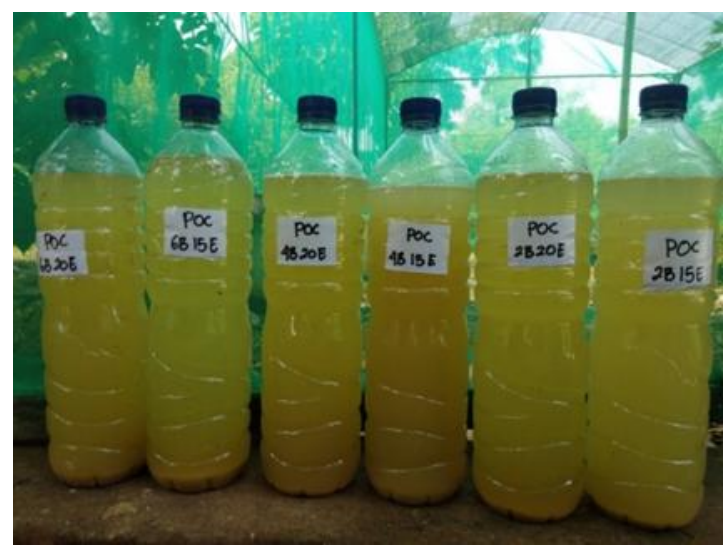

Figure 1. Liquid Organic Fertilizers Made from Star Fruit Waste Using Six Different Formulations

\subsection{Utilization of Star Fruit Waste Liquid Organic Fertilizer to Increase Green Mustard Production}

The best formulation of LOF obtained was made from $4 \mathrm{~kg}$ of star fruit waste and $20 \mathrm{ml}$ of EM4. The LOF along with different levels of inorganic fertilizers then applied to green mustard cultivation in verticulture planting system. The response of green mustard measured in height of plant, width and number of leaf is presented in Table 2. The results from the analysis of variance show that the application of inorganic fertilizer combined with LOF in different concentrations had no significant effect on all three parameters. However, the growth of the green mustard for all three parameters kept increasing as the study went. The average of plant height, leaf width, and number of leaves in week 4 of observation were $19.5 \mathrm{~cm}$, $7.05 \mathrm{~cm}$, and 14.47 leaves respectively.

The number of leaves of green mustard plants was increasing as plants grow. The analysis shows that there is no interaction between inorganic fertilizer and star fruit liquid organic fertilizer. The highest average number of leaves was in the treatment of $9 \mathrm{ml} / \mathrm{l}$ LOF without inorganic fertilizer. The greater number of leaves showed the more nutrient was absorbed by the plant. Sufficient nutrients in the soil helped to increase nutrients in the green mustard plant. In this study, the use of soil with high total $\mathrm{N}$ content helped in providing $\mathrm{N}$ for plants. The use of $9 \mathrm{ml} / \mathrm{l} \mathrm{LOF}$ is also contributed to Nitrogen supply for the green mustard plant.

One of the important nutrients needed by leafy vegetable crops such as green mustard is Nitrogen $(\mathrm{N})$. High Nitrogen content in planting medium (soil) is needed for green mustard to grow optimally (Wibowo \& Asriyanti, 2013). Sufficient N supply will affect leaf growth, thus affecting photosynthesis rate and increase photosynthate (Nerotama, 2014). Adelia (2013) stated that Nitrogen has the function of constructing proteins, nucleic acids, nucleotides, chlorophyll in plants that give color to plants and encourage the growth of organs related to photosynthesis. Gunawan, et al. (2019), The dosage of $50 \%$ inorganic fertilizer and 10 tons of carambola organic fertilizer gave optimum results for the growth of plant height, number of leaves, leaf width, stem diameter, canopy weight, root length and root weight of pakcoy plants. Fertilization using a dose of organic fertilizer 10 tons/ha could reduce $50 \%$ of the need of inorganic fertilizer. 
Table 2. Plant height, leaf width, number of leaves, and leaf color of the green mustard plant with different the dosage of inorganic fertilizer and concentration star fruit LOF

\begin{tabular}{|c|c|c|c|c|c|c|c|c|c|c|c|c|c|c|c|c|}
\hline \multirow[b]{3}{*}{ Treatment } & \multicolumn{16}{|c|}{ Weeks After Planting } \\
\hline & \multicolumn{4}{|c|}{ Plant Height (cm) } & \multicolumn{4}{|c|}{ Width of Leaf (cm) } & \multicolumn{4}{|c|}{ Number of Leaf (leaves) } & \multicolumn{4}{|c|}{ Leaf Colour Chart } \\
\hline & 1 & 2 & 3 & 4 & 1 & 2 & 3 & 4 & 1 & 2 & 3 & 4 & 1 & 2 & 3 & 4 \\
\hline AOP0 & 7.61 & 14.08 & 18.14 & 18.87 & 2.63 & 5.19 & 6.85 & 7.20 & 3.93 & 7.53 & 11.47 & 14.73 & 2.40 & 2.87 & 2.87 & 2.84 \\
\hline $\mathrm{A} 1 \mathrm{P} 0$ & 7.73 & 14.32 & 18.50 & 19.53 & 2.61 & 5.19 & 6.59 & 7.14 & 3.60 & 7.53 & 11.47 & 14.90 & 2.40 & 2.13 & 2.53 & 2.57 \\
\hline $\mathrm{A} 2 \mathrm{P} 0$ & 7.50 & 13.25 & 18.13 & 17.85 & 2.45 & 4.75 & 6.25 & 6.66 & 3.73 & 7.20 & 11.00 & 13.87 & 2.53 & 2.67 & 2.60 & 2.65 \\
\hline A0P1 & 6.73 & 12.91 & 18.10 & 18.87 & 2.38 & 4.83 & 6.56 & 6.95 & 3.53 & 6.87 & 11.00 & 13.93 & 2.20 & 2.27 & 2.67 & 2.52 \\
\hline A1P1 & 7.02 & 13.39 & 18.90 & 19.51 & 2.38 & 4.89 & 6.78 & 7.21 & 3.53 & 7.18 & 10.82 & 14.19 & 2.27 & 2.58 & 2.57 & 2.54 \\
\hline $\mathrm{A} 2 \mathrm{P} 1$ & 7.68 & 13.30 & 18.00 & 18.98 & 2.67 & 5.01 & 6.66 & 7.01 & 3.73 & 7.40 & 11.33 & 14.33 & 2.47 & 2.80 & 3.07 & 2.90 \\
\hline A0P2 & 7.13 & 12.70 & 17.09 & 18.57 & 2.46 & 4.63 & 6.31 & 6.85 & 3.87 & 7.20 & 10.87 & 14.27 & 2.40 & 2.73 & 3.27 & 2.84 \\
\hline A1P2 & 7.01 & 13.13 & 19.18 & 20.36 & 2.42 & 4.75 & 7.01 & 7.35 & 3.73 & 7.00 & 11.80 & 14.40 & 2.27 & 2.40 & 2.73 & 2.64 \\
\hline $\mathrm{A} 2 \mathrm{P} 2$ & 7.43 & 13.18 & 18.60 & 18.11 & 2.57 & 4.91 & 6.60 & 7.09 & 3.93 & 7.33 & 12.07 & 14.55 & 2.47 & 2.73 & 2.87 & 2.79 \\
\hline A0P3 & 7.67 & 13.08 & 18.75 & 20.11 & 2.51 & 4.67 & 6.52 & 7.01 & 3.73 & 7.33 & 11.00 & 15.07 & 2.13 & 2.27 & 2.80 & 2.51 \\
\hline A1P3 & 7.86 & 13.39 & 18.84 & 19.39 & 2.57 & 5.07 & 6.75 & 7.21 & 3.87 & 7.67 & 12.00 & 14.73 & 2.67 & 2.67 & 3.27 & 2.88 \\
\hline A2P3 & 7.69 & 12.84 & 18.01 & 19.41 & 2.82 & 4.77 & 6.62 & 7.10 & 3.87 & 7.60 & 12.33 & 14.87 & 2.60 & 2.80 & 2.93 & 2.78 \\
\hline Average & 7.41 & 13.25 & 18.37 & 19.15 & 2.53 & 4.87 & 6.61 & 7.05 & 3.74 & 7.31 & 11.43 & 14.47 & 2.40 & 2.56 & 2.85 & 2.70 \\
\hline A & ns & ns & ns & ns & ns & ns & ns & ns & ns & ns & ns & ns & * & ns & ns & ns \\
\hline $\mathbf{P}$ & ns & ns & ns & ns & ns & Ns & ns & ns & ns & ns & ns & ns & ns & ns & ns & ns \\
\hline$A \times P$ & ns & ns & ns & ns & ns & Ns & ns & ns & ns & ns & ns & ns & ns & ns & ns & ns \\
\hline Block & ns & ns & ns & ns & ns & Ns & ns & ns & ns & ns & * & ns & $*$ & ns & ns & ns \\
\hline C.V. & 9.69 & 7.83 & 7.74 & 9.28 & 10.3 & 14.74 & 12.97 & 10.84 & 7.86 & 9.22 & 12.69 & 11.77 & 8.79 & 12.65 & 15.75 & 9.58 \\
\hline
\end{tabular}

$\mathbf{A}=$ anorganic factor; $\mathbf{P}=$ Liquid organic fertilizer of star fruit waste factor; $\mathbf{A} \times \mathbf{P}=$ Interaction

$*$ = Significantly difference at $\alpha \leq 10 \%$; ns = not significant by LSD analysis; C.V = Coefficent variance

\subsection{Leaf Color Chart}

The analysis of $\mathrm{N}$ content in the green mustard plants was conducted at transplant using a leaf color chart. Leaf color chart is used to predict the Nitrogen content in a leaf. The observation result of leaf color from one to four weeks after planting shown in Tabel 2. The analysis result showed that the $\mathrm{N}$ need of green mustard plant was met. This indicated by the leaf color of green mustard plant in 4 weeks after planting was 2.70 (on the scale of 4). The lowest leaf color score was 2.51 in treatment of $9 \mathrm{ml} / \mathrm{l} \mathrm{LOF}$ without inorganic fertilizer and the highest was 2.90 in treatment of $3 \mathrm{ml} / \mathrm{l}$ LOF with $100 \%$ inorganic fertilizer dosage at 4 weeks after planting. These results showed that inorganic fertilizer is quite important in supporting chlorophyll formation because of its characteristic that is readily available for the plants. Fauzi, et al. (2019) reported that increasing $\mathrm{N}$ fertilizer raised nitrogen content that indicated with score of leaf colour in Pakcoy (Brassica rapa L.).

Liquid organic fertilizer was not affecting green mustard leaf chlorophyll. The insignificant effect was probably because the genetic effect is more dominant compared to the application of LOF. According to Wijaya, et al. (2015), the chlorophyll of a plant is not only determined by balance soil nutrient but also by its genetic as well as need a good environment including good physical and biological properties of the soil as supporting factors. Besides, the chlorophyll of a plants is affected by plant age, leaf age, leaf morphology, and genetic factor. The older the plant, the more nutrients, water, and light it absorbs for its growth (Setiari \& Nurcahyati, 2009).

\subsection{Shoot Weight}

The response of green mustard in shoot weight variable to the treatments shown in Table 3 . Analysis of variance showed that LOF treatment had a significant effect on green mustard shoot weight. Based on Table 3, the increase of inorganic dosage was not affecting the shoot weight. While the higher LOF concentration, the greater the shoot weight. This showed that the higher LOF concentration probably increasing the microbe activity in the soil, thus making nutrients more available to the plants. The increase in shoot weight was probably because there was Phosphorus content in star fruit waste LOF. Phosphor has important roles in cell division, the formation of protein and fats, and also in the formation of meristematic tissue that can stimulate root growth, which leads to a higher rate of leaf formation (Hardjowigeno, 2007). However, there was report that combination of plant waste compost with inorganic fertilizer increased fresh 
shoot weight of Brassica junceae (Fauzi \& Puspitawati, 2017).

Table 3. Average of green mustard fresh shoot weight with application of inorganic and LOF

\begin{tabular}{cc}
\hline Factor & Average \\
\hline \multicolumn{3}{c}{ Inorganic fertilizer } \\
\hline A0 & 35.046 \\
A1 & 36.764 \\
A2 & 40.003 \\
\hline P0 & \\
P1 & LOF \\
P2 & $33.57 \mathrm{~b}$ \\
P3 & $40.03 \mathrm{~b}$ \\
\hline
\end{tabular}

Note: Number followed by the same letter shows no significant difference based on Least Significant Difference test with $\alpha=10 \%$.

\section{CONCLUSION}

This study informed that based on the qualitative test, the best LOF formulation made from star fruit waste was $4 \mathrm{~kg}$ of star fruit waste $+20 \mathrm{ml}$ EM4 that has criteria of brownish-yellow color, pungent fermented odor, and white layer in the surface of LOF. The best LOF formulation then applied to green mustard cultivation in verticulture planting system. The experiment result of that application was that LOF up to a concentration of $9 \mathrm{ml} / \mathrm{L}$ can increase shoot weight. However, LOF application combined with inorganic fertilizer has no significant effect on green mustard vegetative parameters. Further development of LOF formula and testing is needed to obtain information about its effect on vegetative growth as well as plant yield.

\section{ACKNOWLEDGMENT}

Thank you to Ministry of Research, Technology, and Higher Education, Republic of Indonesia for Grant by Young Lecturer Research scheme with No 037/KM//PNT/2019 and contract No 116/TRILOGI/ $\mathrm{LPPM} / \mathrm{KP} / 5 / 2019$ to this study. Thank you to Agroedutourism Attaqie Farm that facilitated for this study. Also Thank you to Restu Pramudi and Rio Johansen Siahaan, Agrotechnology Trilogy University student who helped with the experiments in this study.

\section{REFERENCES}

Afifi, M. F. (2007). Analisis Kepuasan Konsumen terhadap Atribut Sayuran Organik dan Penerapan Personal SellingBenny's Organic Garden.[Skripsi]. Sarjana Ekstensi Manajemen Agribisnis, Fakultas Pertanian, Institut Pertanian Bogor. Bogor.

Bayuseno, A. P. (2009). Penerapan Dan Pengujian Model Teknologi Anaerob Digester Untuk Pengolahan Sampah Buah-Buahan Dari Pasar Tradisional. ROTASI, 11(2), 5-12.
Fadhilah, A., Sugianto, H., Hadi, K., Firmandhani, S. W., Murtini, T. W., \& Pandelaki, E. E. (2011). Kajian Pengelolaan Sampah Kampus Jurusan Arsitektur Fakultas Teknik Universitas Diponegoro. Modul, 11(2).

Fauzi, A. R., \& Puspitawati, M. D. (2017). Pemanfaatan Kompos Kulit Durian untuk Mengurangi Dosis Pupuk N Anorganik pada Produksi Tanaman Sawi Hijau (Brassica junceae). Agrotrop: Journal on Agriculture Science, 7(1), 22-30. https://doi.org/10.24843/AJoAS. 2017.v07.i01.p03.

Fauzi, A.R., Casdi, \& Warid. (2019). Respon Tanaman Pakcoy (Brassica rapa L.) terhadap Pemberian Pupuk Organik Cair Limbah Perikanan. Jurnal Hortikultura Indonesia, 10(2), 94-101. https://doi.org/10.29244/jhi.10.2.94-101.

Hadisuwito, S. (2007). Membuat pupuk kompos cair. AgroMedia.

Hardjowigeno. (2007). Ilmu Tanah. Jakarta: Penerbit Akademika Pressindo.

Gunawan, H., Puspitawati, M. D., \& Sumiasih, I. H. (2019). Pemanfaatan Pupuk Organik Limbah Budidaya Belimbing Tasikmadu Tuban Terhadap Pertumbuhan dan Hasil Produksi Tanaman Pakcoy (Brassica rapa L.). Jurnal Bioindustri, 2(1), 413-425.

Hardiansyah, P., Nurjanah, U., \& Widodo, W. (2019). Growth Response and Yield of Pakcoy (Brassica rapa L.) on Various Concentrations Liquid Organic Fertilizer of Jiringa Hulls [Phithecellobium jiringa (Jack) Prain Ex King]. Akta Agrosia, 22(2), 1-7.

Novizan, I. (2005). Petunjuk Pemupukan yang Efektif. AgroMedia Pustaka, Jakarta.

Nerotama, S., Kushendarto, \& Ginting, Y. C. (2014). Pengaruh Dua Jenis Pupuk Daun Dan Dosis Pupuk Npk Terhadap Pertumbuhan Vegetatif Awal Tanaman Jambu Biji (Psidium guajava L.) Kultivar Citayam (Doctoral dissertation, FAKULTAS PERTANIAN).

Phibunwatthanawong, T., \& Riddech, N. (2019). Liquid organic fertilizer production for growing vegetables under hydroponic condition. International Journal of Recycling of Organic Waste in Agriculture, 8(4), 369-380.

Sopha, G. A., \& Uhan, T. S. (2013). Application of liquid organic fertilizer from city waste on reduce urea application on Chinese mustard (Brassica juncea L) cultivation. Advances in Agriculture \& Botanics, 5(1), 39-44.

Yulnafatmawita, Y., Naldo, R. A., \& Rasyidin, A. (2012). Analisis sifat fisika Ultisol tiga tahun setelah pemberian bahan organik segar di daerah tropis basah Sumbar. Jurnal Solum, 9(2), 91-97. 